\title{
Influence of the nutritional level and pre-sowing seed treatment on the yield of spring wheat
}

\author{
Marat Amirov*, Dmitry Toloknov, Ayrat Safiullin and Pavel Semenov \\ Kazan State Agrarian University, 65, K. Marks str., Kazan, 420015, Republic of Tatarstan, Russia
}

\begin{abstract}
It remains relevant to meet the needs of plants in nutrients, methods of using growth stimulants, considering the active phases of culture development. The purpose of our research is to study the complex effect of the level of mineral nutrition, pre-sowing treatment of seeds, and spraying growing plants with a growth regulator on the productivity of spring wheat. Laboratory research and field experiments were carried out in 2019-2020 based on the Federal State Budgetary Educational Institution in the field of Higher Education "Kazan State Agrarian University" on gray forest soil. The average yield of spring wheat over the years of research against the background without fertilizers was $3.94 \mathrm{t} / \mathrm{ha}$, against the background of NPK to obtain $3.5 \mathrm{t} / \mathrm{ha}$ of grain $-4.53 \mathrm{t} / \mathrm{ha}$, against the background of NPK to obtain $4.5 \mathrm{t} / \mathrm{ha}$ of grain $-5.24 \mathrm{t} / \mathrm{ha}$. The complex use of growth stimulants during pre-sowing seed treatment and double spraying in the tillering phase and spring wheat into the tube contributed to an increase in yield in all nutritional backgrounds by another $4.9-6.3 \%$.
\end{abstract}

\section{Introduction}

The annual production of stable yields of wheat grain remains the most important task of the farmers of the Republic of Tatarstan. To accomplish this task, at the beginning it is necessary to form leveled shoots [1-3]. Spring wheat in the phase of full sprouting does not have a powerful root system that can compete with weeds. For the accelerated development of roots, it is necessary to create optimal conditions for their growth - this is access to moisture, air, and nutrients [4-6]. For the same purpose, according to many researchers, is the use of growth stimulants during pre-sowing seed treatment and during vegetation [7-9].

The purpose of our study is to study the complex effect of mineral nutrition, pre-sowing seed treatment, and spraying plants with growth stimulants during the active phases of spring wheat development.

\section{Research methods and techniques}

The research was carried out on gray forest soils of the experimental field of the Federal State Budgetary Educational Institution in the field of Higher Education Kazan State Agrarian University in 2019-2020. The content in the arable layer of humus is more than $3.0 \%$, mobile phosphorus (according to Kirsanov) is very high (more than $250 \mathrm{mg} / \mathrm{kg}$ ), exchangeable potassium is increased $(121-170 \mathrm{mg} / \mathrm{kg})$, had a neutral reaction of the medium (pH 6.1-7,0).

The field experiment scheme provided for the study of the following options:

Mineral nutrition background (factor A) -
- without fertilizers (control);

- calculation of fertilizers by the balance method (N36P23K35) for a grain yield of $3.5 \mathrm{t} / \mathrm{ha}$;

- calculation of fertilizers by the balance method (N94P83K77) for a grain yield of $4.5 \mathrm{t} / \mathrm{ha}$.

Seed treatment and spraying of crops (factor B) -

1. Control (disinfectant fungicide Vial Trust $0.5 \mathrm{l} / \mathrm{t}$ );

2. Treater $0.5 \mathrm{l} / \mathrm{t}$ and spraying of crops in the tillering phase with growth regulator Stimax Growth 1 1/ha;

3. Treater $0.51 / t+$ Stimax $0.51 / t$ and spraying crops in the tillering phase Stimax Growth $11 /$ ha;

4. Treater $0.5 \mathrm{l} / \mathrm{t}+$ Stimax $0.5 \mathrm{l} / \mathrm{t}$ and spraying crops in the tillering phase Stimax Growth $11 / \mathrm{ha}$, in the phase of entering the tube Nutrivant Plus $2 \mathrm{~kg} / \mathrm{ha}$.

The experiments were carried out in four repetitions, the plots were placed sequentially, the area of the registration plots was $25 \mathrm{~m}^{2}$. The object of the study was spring wheat of the Ulyanovskaya 105 variety. Mathematical processing of the research results was carried out according to B.A. Dospekhov using programs for Microsoft Excel [10].

\section{Results and its discussion}

For 2019-2020 field germination of spring wheat when using the Vial Trust dressing agent $0.51 / \mathrm{t}$ against the background without fertilizers was 68.6-69.1 \% (Fig. 1).

Joint treatment of seeds with a $0.5 \mathrm{l} / \mathrm{t}$ seed dressing agent and a $0.5 \mathrm{l} / \mathrm{t}$ stimulator of growth Stimax against the same background made it possible to increase field germination by $1.4-2.2 \%$. Against the background of NPK by $3.5 \mathrm{t} / \mathrm{ha}$ of grain, the difference in field

\footnotetext{
Corresponding author: m.f.amirof@ rambler.ru
} 
germination with joint treatment and treatment with only a dressing agent was $3.3 \%$, and against the background of NPK by $4.5 \mathrm{t} / \mathrm{ha}$ of grain, respectively $-4.5 \%$. Field germination at the first level of NPK feeding by $3.5 \mathrm{t} / \mathrm{ha}$ of grain was $5.2 \%$ higher than the background without fertilization. The safety of spring wheat seedlings to harvesting when the seeds were treated with a seed dressing agent alone against the background without fertilizers was $87.1 \%$, against the background of NPK by $3.5 \mathrm{t} /$ ha of grain $86.4-87.2 \%$, against the background of NPK by 4.5 t/ha of grain $86.1-86.6 \%$ (Fig. 2).

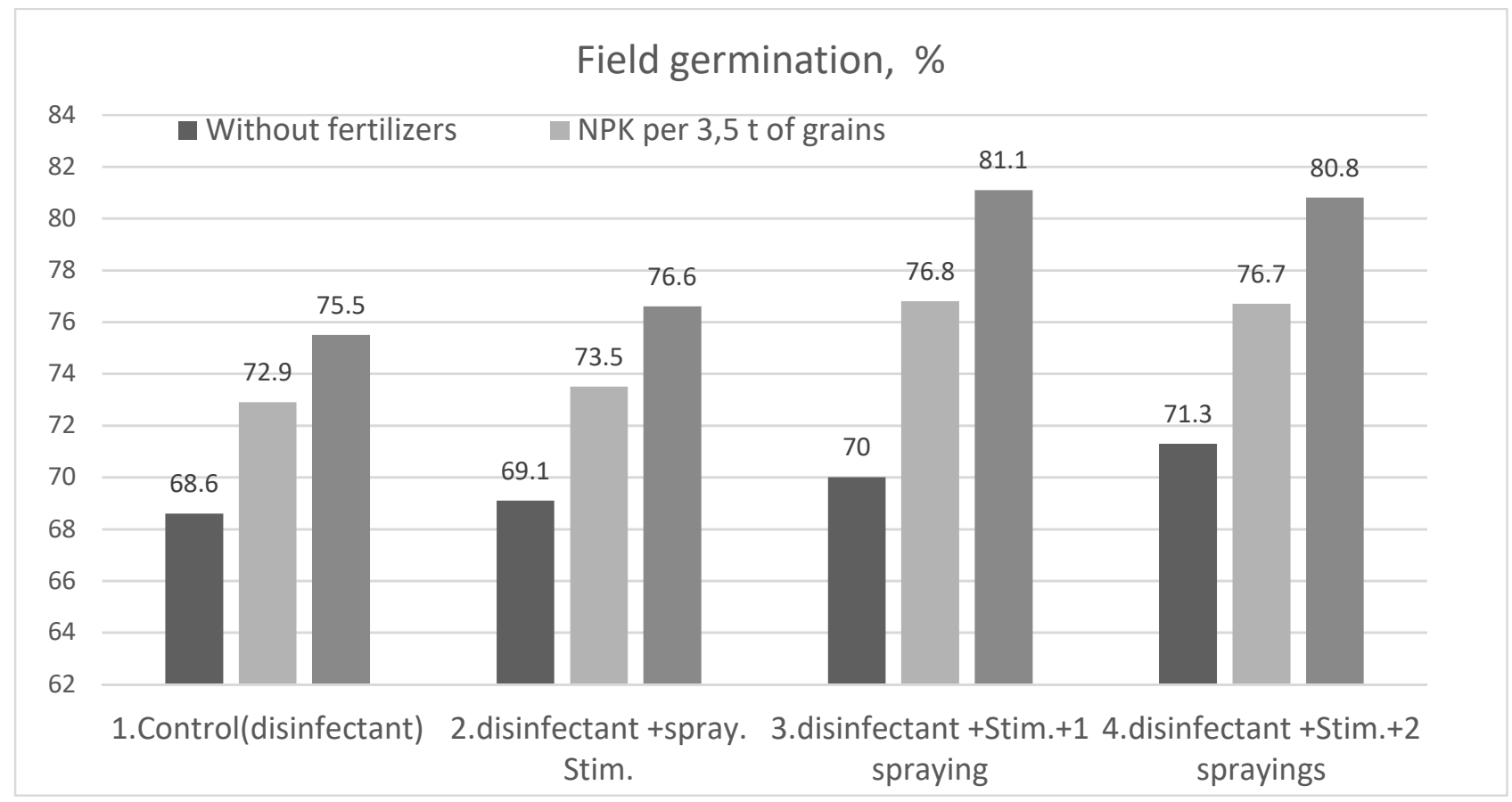

Fig. 1. Field germination of spring wheat using mineral fertilizers, seed treatment and spraying of crops, 2019-2020

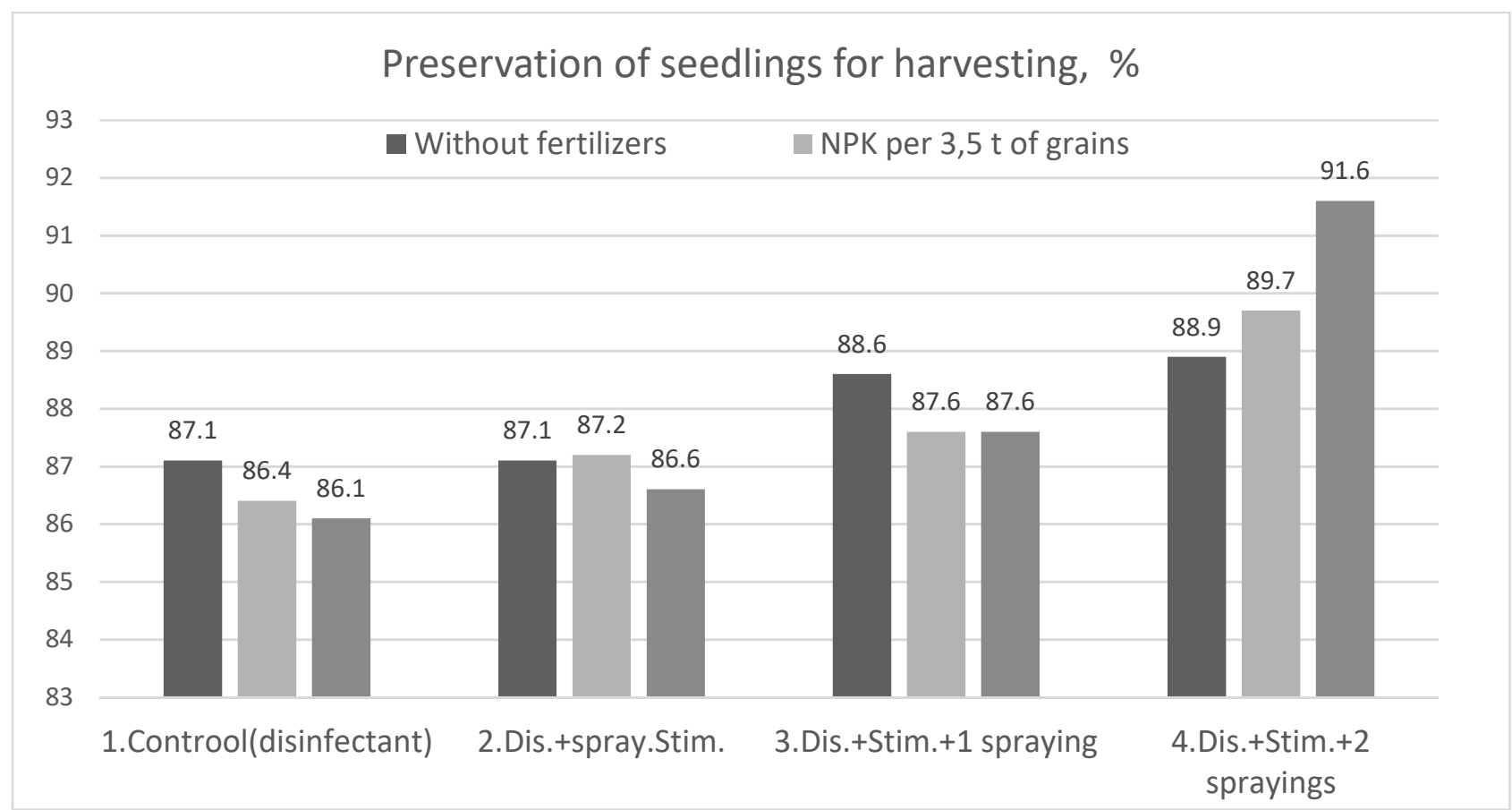

Fig. 2. Safety of spring wheat seedlings for harvesting depending on seed treatment, crop spraying and fertilization, 2019-2020

The complex use of the seed dressing agent Vial Trust and the growth stimulator Stimax during presowing treatment and when spraying crops in the tillering phase of Stimax wheat Growth of 1 1/ha, in the phase of entering the tube Nutrivant Plus $1.8 \%$, against the background of NPK by $3.5 \mathrm{t} /$ ha of grain - by $2.5 \%$, against the background of NPK by 4.5 t/ha of grain - by $5.5 \%$. The preservation of spring wheat was influenced by the temperature regime, the presence of moisture, and forms of nutrients available to plants in certain phases of development. In the years of research, the reserves of productive moisture in a meter layer of soil for sowing 
spring wheat amounted to $174-182 \mathrm{~mm}$, decreasing to the phase of entering the tube to $122-130 \mathrm{~mm}$, to harvesting to $86-94 \mathrm{~mm}$. During the growing season of spring wheat in $2019,253 \mathrm{~mm}$ of precipitation fell, in $2020-155 \mathrm{~mm}$.

Spring wheat yield on average for 2019-2020 against the background without the use of fertilizers when treating seeds Vial Trust $0.51 / \mathrm{t}$ was $3.94 \mathrm{t} / \mathrm{ha}$ when treating seeds Vial Trust + Stimax and spraying in the tillering phase Stimax Growth - $4.11 \mathrm{t} /$ ha (Table 1).

Against the background of NPK by $3.5 \mathrm{t} / \mathrm{ha}$ of grain during seed treatment with a growth stimulator and spraying in the tillering phase of spring wheat, the average yield was $4.67 \mathrm{t} / \mathrm{ha}$, which is $3 \%$ higher than the control, and with additional processing the phase of entering the tube Nut-rivant Plus - $4.75 \mathrm{t} / \mathrm{ha}$, which is $4.9 \%$ more than the control. Against the background of NPK by $4.5 \mathrm{t} / \mathrm{ha}$ of grain with the use of growth stimulants on seed treatment and one spraying, the yield is higher than the control by $4.4 \%$, with seed treatment and two sprays of crops - by $6.3 \%$.

The use of growth stimulants in the tillering and tubing phase of spring wheat helped to improve the quality of the grain due to an increase in the nitrogen content in the leaves, spikelet, and flower scales, from where it later enters the grain. Yield growth with such spraying is not always observed, and then only due to an increase in the mass of 1000 grains since by the time of spraying, the rest of the productivity elements of the wheat plant have already been formed (Fig. 3).

The mass fraction of gluten in the grain of spring wheat against a background without fertilizers, when using a seed dressing agent and spraying in the biting phase of Stimax Growth was $26.9 \%$ (Fig. 4).

Against the same background, nutrition during the treatment of seeds with a disinfectant, growth stimulator Stimax, and spraying in the tillering phase of Stimax Growth, the mass fraction of gluten increased to $27.8 \%$, and with additional processing and in the howling wheat Nutrivant Plus reached 28.6\%. Against the background of NPK by $3.5 \mathrm{t} / \mathrm{ha}$ of grain during seed treatment with a seed dressing agent and spraying during the tillering phase of spring wheat with a growth stimulant, the mass fraction of gluten was $23.4 \%$, which is $9.8 \%$ higher than the control, and when seeds were treated with a stimulant Sti -max and spraying of crops Stimax Growth and Nut-rivant Plus reached $28.4 \%$.

Table 1. Spring wheat yield ( $\mathrm{t} / \mathrm{ha}$ ) with the use of mineral fertilizers, seed treatment and spraying of crops, 2019-2020

\begin{tabular}{|c|c|c|c|c|}
\hline \multirow{2}{*}{$\begin{array}{c}\text { Mineral } \\
\text { nutrition } \\
\text { background }\end{array}$} & \multicolumn{4}{|c|}{ Seed treatment and crop spraying } \\
\hline & $\begin{array}{l}\text { 1. Control (Treater } \\
\text { Vial Trust } 0.51 / t \text { ) }\end{array}$ & $\begin{array}{l}\text { 2. Processor; } \\
\text { spraying in the } \\
\text { tillering } \\
\text { phase Stimax } \\
\text { Growth (11/ha) }\end{array}$ & $\begin{array}{l}\text { 3. Treater }+ \text { Stimax } \\
(0.5 \mathrm{l} / \mathrm{t}) \text {; spraying } \\
\text { in the tillering phase } \\
\text { Stimax Growth } \\
(11 / \mathrm{ha})\end{array}$ & $\begin{array}{l}\text { 4. Treater + Stimax }(0.5 \mathrm{l} / \mathrm{t}) ; \\
\text { spraying } \\
\text { in the tillering phase Stimax } \\
\text { Growth }(1 \mathrm{l} / \mathrm{ha}) \text {; spraying in the } \\
\text { phase of entering the tube Nut- } \\
\text { rivant Plus }(2 \mathrm{~kg} / \mathrm{ha})\end{array}$ \\
\hline \multicolumn{5}{|c|}{2019} \\
\hline No fertilizers & 4.95 & 5.03 & 5.23 & 5.25 \\
\hline $\begin{array}{l}\text { NPK for } 3.5 \mathrm{t} / \mathrm{ha} \text { of } \\
\text { grain }\end{array}$ & 5.70 & 5.75 & 5.84 & 5.97 \\
\hline $\begin{array}{l}\text { NPK for } 4.5 \mathrm{t} / \mathrm{ha} \text { of } \\
\text { grain }\end{array}$ & 6.53 & 6.62 & 6.68 & 6.79 \\
\hline Average & 5.73 & 5.80 & 5.92 & 6.00 \\
\hline $\mathrm{LSD}_{05}$ for & \multicolumn{4}{|c|}{$\begin{aligned}(\mathrm{A})=0.372 ;(\mathrm{B}, \mathrm{AB}) & =0.155 ; \\
\text { (private secondary) } & =0.268\end{aligned}$} \\
\hline \multicolumn{5}{|c|}{2020} \\
\hline No fertilizers & 2.92 & 2.95 & 2.99 & 3.02 \\
\hline $\begin{array}{l}\text { NPK for } 3.5 \mathrm{t} / \mathrm{ha} \text { of } \\
\text { grain }\end{array}$ & 3.36 & 3.49 & 3.50 & 3.53 \\
\hline $\begin{array}{l}\text { NPK for } 4.5 \text { t/ha of } \\
\text { grain }\end{array}$ & 3.94 & 4.24 & 4.26 & 4.34 \\
\hline Average & 3.41 & 3.56 & 3.58 & 3.63 \\
\hline $\mathrm{LSD}_{05}$ for & \multicolumn{4}{|c|}{$\begin{aligned}(\mathrm{A})=0.215 ;(\mathrm{B}, \mathrm{AB}) & =0.044 \\
(\text { private secondary }) & =0.076\end{aligned}$} \\
\hline \multicolumn{5}{|c|}{ Average for $2019-2020$} \\
\hline No fertilizers & 3.94 & 3.99 & 4.11 & 4.14 \\
\hline $\begin{array}{c}\text { NPK for } 3.5 \text { t/ha of } \\
\text { grain }\end{array}$ & 4.53 & 4.62 & 4.67 & 4.75 \\
\hline $\begin{array}{c}\text { NPK for } 4.5 \mathrm{t} / \mathrm{ha} \text { of } \\
\text { grain }\end{array}$ & 5.24 & 5.43 & 5.47 & 5.57 \\
\hline
\end{tabular}




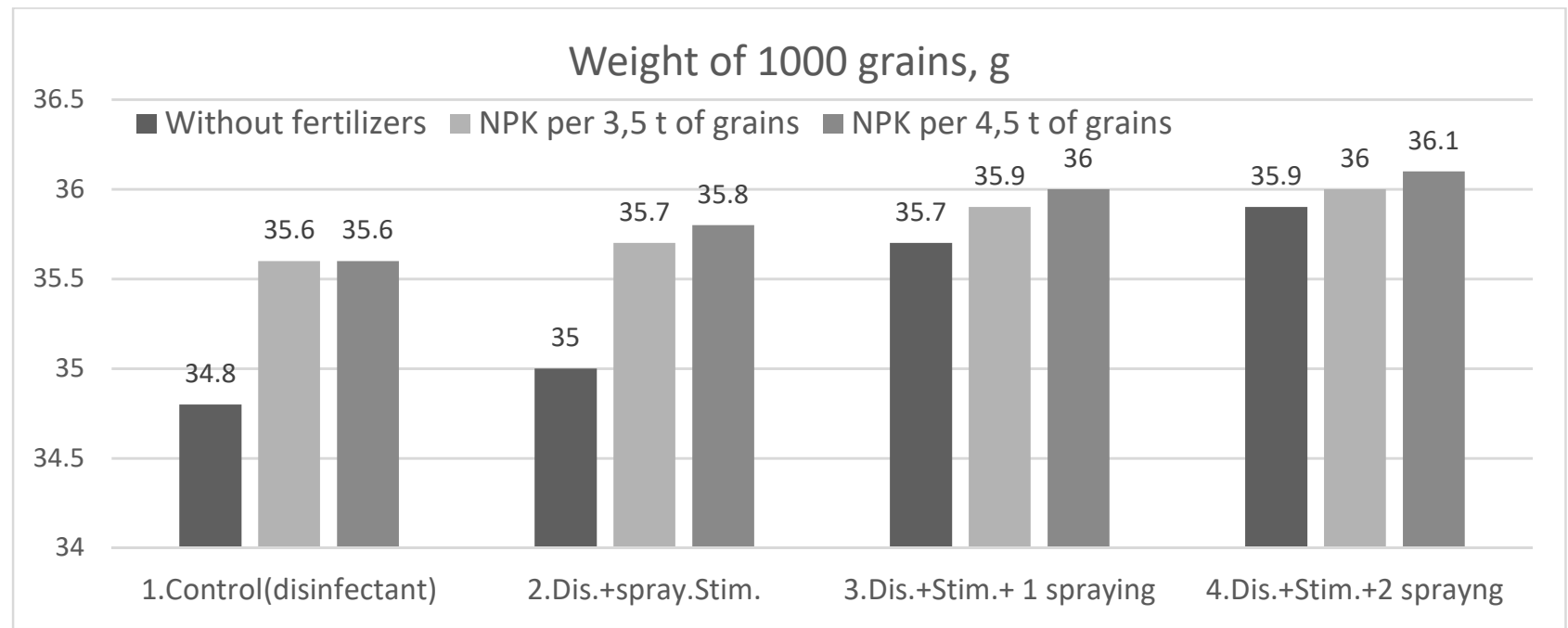

Fig. 3. Weight of 1000 grains of spring wheat, depending on seed treatment, spraying of crops and fertilization, 2019-2020

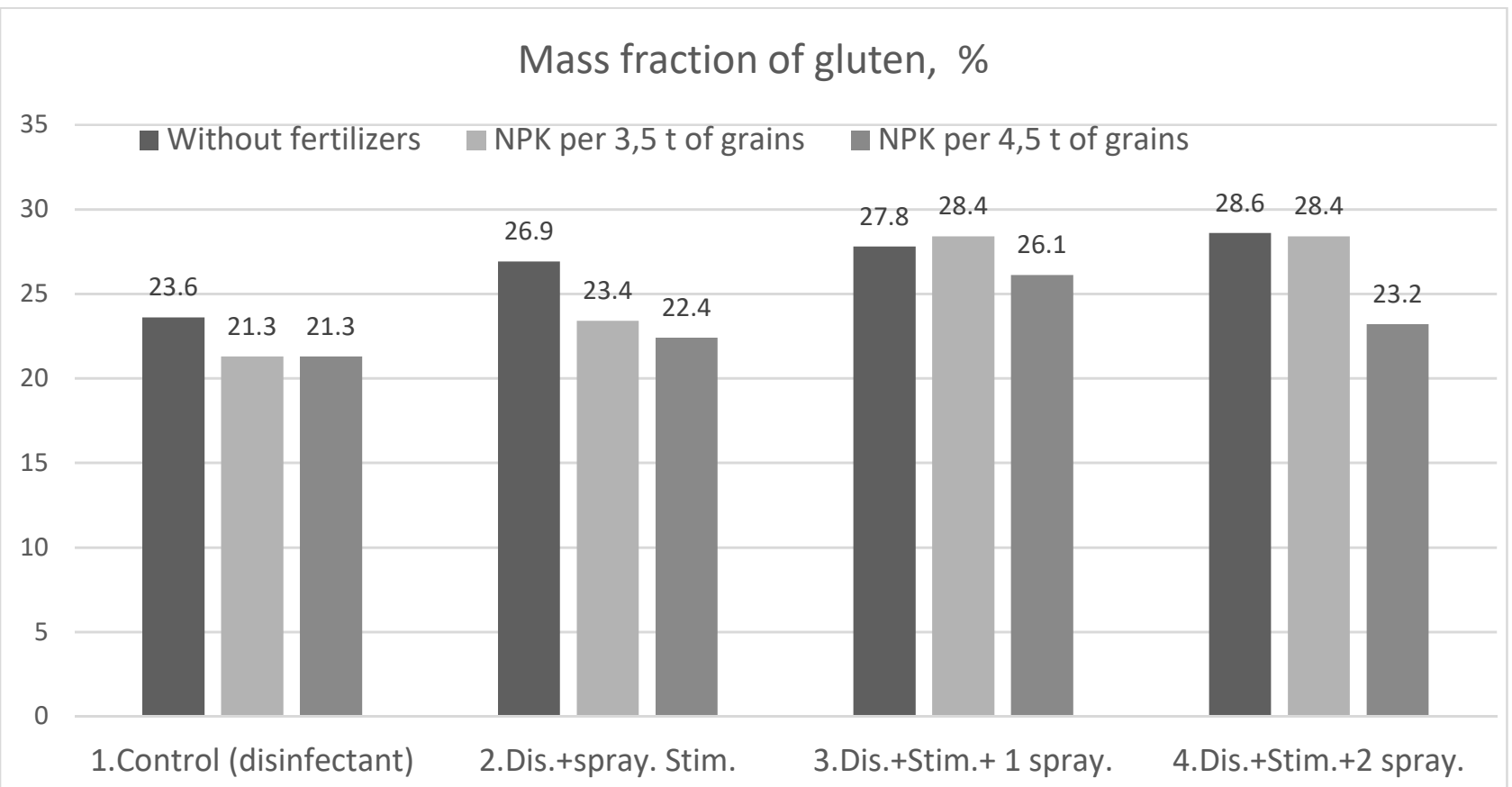

Fig. 4. Mass fraction of gluten in spring wheat grain depending on seed treatment, spraying of crops and fertilization, 2019-2020

\section{Conclusion}

To increase the yield of spring wheat, it is necessary to use the calculation and balance method of applying mineral fertilizers, growth stimulators during pre-sowing seed treatment and spraying crops in the tillering and stemming phase.

\section{References}

1. F. Sh. Shaikhutdinov, I. M. Serzhanov, M. F. Amirov, A. R. Valiev, R. M. Nizamov, Improvement of cultivation technology for spelt in Tatarstan Republic, IOP Conf. Series: Earth and Environmental Science, 341, 012091 (2019). doi:10.1088/1755-1315/341/1/012091.
2. R. Sabirov, A. Valiev, L. Karimova, A. Dmitriev, D. Khaliullin, Influence of physical factors on viability of microorganisms for plant protection, 18th International Scientific Conference Engineering for Rural Development Proceedings (May 22-24, Jelgava), Vol. 18, pp. 555-562 (2019). DOI: 10.22616/ERDev2019.18.N211.

3. V.I. Kostin, F.A. Mudarisov, A.I. Krivova, Influence of microelements-synergists on the baking properties of winter wheat grain, Bulletin of the Russian Academy of Natural Sciences, 6, 54-57 (2014).

4. T.L. Kurnosova, L.V. Osipova, I.V. Vernichenko et al., The formation of wheat productivity (Tritikum aestivum L.) and triticale against the background of pre-treatment with selenium, silicon and zinc under conditions of oxidative stress caused by drought,

\footnotetext{
* Corresponding author: m.f.amirof@rambler.ru
} 
Problems of agrochemistry and agroecology, 3, 1323 (2017).

5. M. Amirov, F. Shaikhutdinov, I. Serzhanov, A. Serzhanova, Main directions of development of agro-technologies for production of spring wheat species for sustainable agriculture in the foreststeppe of the middle Volga region, BIO Web of Conferences, 17, 00071 (2020).

6. R. Minikayev, L. Gaffarova, The effect of bacterial preparations on the growth, development and quality indicators of sugar beet yield, BIO Web of Conferences, 17, 00250 (2020)

7. A. M. Sabirzyanov, N. A. Loginov, I. P. Talanov, M. V. Panasyuk, T. G. Hadeyev, Influence of background of mineral nutrition and receptions of major treatment of soil when cultivating spring wheat in conditions of the forest-steppe zone of the middle Volga region, IOP Conf. Series: Earth and Environmental Science, 341, 012027 (2019). doi:10.1088/1755-1315/341/1/012027

8. M.Yu. Gilyazov, Changes in agrophysical properties of leached chernozem upon its contamination by commercial oil in the Republic of Tatarstan, Eurasian Soil Science, 35(12), 1341-1345 (2002).

9. R.I. Safin, L.Z. Karimova, S.Z. Validov, The evaluation of various sources of endophytic microorganisms for new biofungidides, The proceedings of International forum «Biotechnology: state of the art and perspectives» (May 23-25), pp. 34-35 (2018).

10. B.A. Dospekhov, Methodology of field experience (with the basics of statistical processing of research results) (Moscow: Kolos, 1985) 416 p. 